\title{
Construction Health and Safety Awareness of Nigerian Undergraduate Quantity Surveyors
}

\author{
Okorie, V.N. ${ }^{1, *}$ and Ogbu, C.P. ${ }^{1}$ \\ ${ }^{1}$ Department of Quantity Surveying, University of Benin, Benin City, Nigeria \\ Corresponding Author: *victor.okorie@ uniben.edu
}

\begin{abstract}
Construction is particularly an accident-prone and disease-causing process. Quantity surveyors render professional financial management services with regards to the entire construction value chain - including in construction health and safety (H\&S) management. However, the adequacy of the construction $\mathrm{H} \& S$ content of quantity surveying undergraduate programmes in Nigerian universities is uncertain. This study examined undergraduate quantity surveyors' knowledge of construction H\&S. The study used purposive sampling technique for the selection of five universities in southern Nigeria offering bachelor's degree in quantity surveying. Copies of the study questionnaire were given to 400 and 500 levels students from the five selected universities. Interviews were conducted with registered practicing quantity surveyors, and one quantity surveying lecturer in each of the universities in order to validate the results of the survey. The data were analysed using mean scores. The results revealed that undergraduate students of quantity surveying in the universities covered by the study are insignificantly aware of quantity surveyors' construction H\&S roles. An examination of the course contents of the undergraduate quantity surveying programmes of the universities did not reveal any separate course module for construction $H \& S$. The interviews supported the findings from the survey carried out on the students. They revealed that there is need to include construction $\mathrm{H} \& \mathrm{~S}$ in quantity surveying undergraduate programmes in Nigerian universities. Undergraduate quantity surveying students should be taught construction $H \& S$ in order to equip them for their future $\mathrm{H} \& \mathrm{~S}$ management roles in the construction industry.
\end{abstract}

Keywords: Construction, Education, Health and Safety, Quantity Surveying

\subsection{Introduction}

Education is meant to inculcate in the individual the appropriate skills required to face tomorrow's challenges. Ofoegbu (2004) contended that education is the acquisition of the right values, attitudes, ethics, discipline, knowledge and skills for life's adventure. Education and training play a key role in the development of awareness and understanding of the specific hazards and risks associated with construction operations and its environment (Oloke, 2010; Lutchman, Maharaj \& Ghanem, 2012). In the construction context, education empowers future construction managers to act proactively in the management of health and safety (H\&S) (Hughes \& Ferrett, 2010). Stressing the importance of construction H\&S education among the built environment professionals, Haupt (2010) stated that it is a vehicle that drives workplace H\&S culture. Lingard and Rowlinson (2005) and Hughes and Ferrett (2010) asserted that inadequate H\&S education impacts negatively on students' competencies, skills, knowledge and H\&S awareness. As pointed out by Smallwood (2004), construction H\&S education is not only beneficial to the employers, but it also leads to a positive attitudinal orientation of the built environment undergraduates who are the future professionals and managers in the construction industry. In Luria's (2011) opinion, H\&S education and training is a prerequisite for an appropriate level of awareness relative to $H \& S$, which in turn is a prerequisite for the development of an optimum $H \& S$ culture. Inadequate safety education has been identified as one of the causes of failure of H\&S in construction projects (Nishgaki, 1994). In Nigeria, the level of awareness of construction H\&S roles by undergraduate quantity surveyors has not been adequately researched. Health, Safety and Executive (HSE) (2010) affirmed that it is necessary to develop a 'safety-first mindset' among students long before they get into the workplace in order to be adequately prepared for their future H\&S roles. 
Corroboratively, HSE (2011) stated that education and training create awareness and engender behavioural change among workers and designers. HSE (2010) maintained that a preventative H\&S culture should be one that incorporates H\&S into the educational system of construction industry's future professionals and managers. Thus, quantity surveying undergraduate students in Nigeria should be trained to understand both national and international laws, regulations and conventions of construction $\mathrm{H} \& \mathrm{~S}$ in order to be fit for their future roles.

Despite the importance of $H \& S$ education and training, construction $H \& S$ is not specified as a separate course in the curriculum of quantity surveying programmes at the undergraduate level in Nigeria [National Universities Commission (NUC), 2007]. The effects of this situation on Nigerian quantity surveyors' awareness of construction H\&S management remains poorly studied. Poor level of awareness of the importance of construction $H \& S$ by quantity surveying students could be one of the factors contributing to site accidents in Nigeria. Quantity surveyors often act as cost allocators in construction projects as they distribute the total cost to specific items in a project. Evidently, their knowledge of construction $\mathrm{H} \& \mathrm{~S}$ affects the financial provision for $\mathrm{H} \& \mathrm{~S}$ in most construction projects. Inadequate financial provision for construction $H \& S$ management will result in problems such as continuous absenteeism of workers due to injury and low productivity, and consequently, a reduction in contractors' profit margin (Hinze, 2006; Okorie, 2014). On the clients' side, it will possibly lead the client to paying higher insurance premiums and being inundated with claims. Globally, the estimated cost of poor H\&S management is $4 \%$ of the world's gross domestic product (GDP) [International Labour Organisation (ILO), 2011]. Hinze (2006: 34) rightly observed that, 'injuries cost, safety pays.' Safe work practices not only pay in terms of financial gain, but also in terms of company corporate image, which is equally very important (ILO, 2010). Much has been researched on H\&S management and causes of construction site accidents in Nigeria (Idoro, 2008; Udo, Usip \& Asuquo, 2016), but scarcely has any research been conducted that explored the awareness of construction H\&S by Nigerian quantity surveying undergraduates.

Smallwood (2004) and Gambatese (2008) held the opinion that H\&S education and training are the important tools for increasing the general awareness, knowledge and understanding of the concepts of hazards and risks, and how they may be controlled in construction sites. After over 200 visits to design offices in 2008/09, HSE (2010) concluded that designers, including quantity surveyors, had an inadequate understanding of construction safety, health and welfare. The report further stated that the majority of designers were unaware of the 'General Principles of Prevention' and that only $12 \%$ of designers had H\&S qualification. Mohd-Kamar, Lop, Mat-Salleh, Mamter and Suhaimi (2014) studied contractors' awareness of occupational safety and health $(\mathrm{OSH})$ management systems in the construction industry. They found that majority of the class A contractors were aware of the importance of construction H\&S. The study did not focus on undergraduates, and so it differs from the present study, even though both studies are similar in investigating the level of awareness of construction H\&S. Need exists, therefore, to ascertain the extent to which university education prepares student quantity surveyors for roles in construction H\&S management. A research conducted in South Africa by Smallwood (2004) on the need for inclusion of construction H\&S course in architectural curriculum concluded that not only is $\mathrm{H} \& \mathrm{~S}$ important to architectural students, but it is also vital to other built environment programmes such as building, construction management and quantity surveying. Additionally, the study stated that the students need an appreciation of construction H\&S management in their formative years as an essential tool for the overall construction industry H\&S improvement. Studies have shown that a large percentage of contractors who do not provide personal protective equipment (PPE) to site workers do not make provision for H\&S in their tenders (Hinze, 2006). Also, Okorie (2014) found that inadequate allocation of financial resources for H\&S by quantity surveyors during the project planning or at the tendering stage is a serious challenge to $H \& S$ improvement. Famakin and Fawehinmi (2012) sought to assess quantity surveyors' perception of construction health and safety regulations in Nigeria, and concluded that construction H\&S regulations have direct impact on project delivery in Nigeria. Nevertheless, the study did not answer the question whether the direct impact is related to the construction H\&S education of the professionals involved in the projects. Okoye et al., (2016) examined the H\&S knowledge and compliance of building construction workers on sites in Anambra State, Nigeria. It was found that a strong positive correlation exists between construction $\mathrm{H} \& \mathrm{~S}$ knowledge and the performance of the projects covered by the study. However, the study was not 
focused on quantity surveyors, and it remained silent on how the respondents gained the knowledge of construction H\&S.

European Agency for Safety, Health and Welfare at Work (2011) held that occupational H\&S has become an integral part of business management, and that all future managers and professionals need relevant H\&S education. Consequently, quantity surveying students need to have an appreciation of both national and international $\mathrm{H} \& \mathrm{~S}$ laws and regulations during their undergraduate studies. The objective of this study is to examine undergraduate quantity surveyors' level of awareness of construction H\&S management roles of quantity surveyors with a view to making policy recommendations for the training of quantity surveyors in Nigeria.

\subsection{Importance of Construction H\&S Management}

Construction sites have very poor reputation for safety (Mohamed, 2002), and unsatisfactory compliance with $\mathrm{H} \& \mathrm{~S}$ standards has been reported in the Nigerian construction industry (Okoye, Ezeokonkwo \& Ezeokoli, 2016). The implications of these are enormous. For example, most construction firms in Nigeria are small and medium scale indigenous construction firms that are struggling to survive. When accidents occur in projects handled by such firms, they can erode the firms' entire profit. Accidents at construction sites have the potential to take $30 \%$ off company annual profits, and failure to manage safety has a much larger social cost (Arewa \& Farrell, 2012). Health and safety, therefore, is an economic as well as humanitarian concern that requires proper management control (Muiruri \& Mulinge, 2014:1). This connection between construction H\&S and project profitability underscores quantity surveyors' construction H\&S education.

One obvious effect of poor construction sites H\&S is the human suffering caused workers' families, which cannot be compensated with money. The other potential effect is the high compensation paid to the workers or to their families. There are grievous economic consequences on the families for losing their dear ones. Apart from this, poor site H\&S management tarnishes a contractor's image (Spangenberg, 2009). The tarnished image is often accompanied with adverse publicity, which results in a contractor losing future tenders. Given this scenario, undergraduate quantity surveyors should be knowledgeable enough about construction $\mathrm{H} \& \mathrm{~S}$ to offer prudent construction $\mathrm{H} \& \mathrm{~S}$ cost management advices to their firms upon graduation. The skill to give such professional advice may determine the employability of graduate quantity surveyors in Nigeria. Sodipo (2014) observed that most Nigerian graduates are found unemployable due to skill deficiencies, and construction H\&S is one of such skills for graduate quantity surveyors.

Ayudhya and Israngkura (2011) showed that poor construction H\&S management may lead to lengthy construction disputes. With the economic and social implications of poor construction H\&S on workers, their families, contractors and governments, there is need to examine the Nigerian undergraduate quantity surveyors' awareness of construction H\&S.

\subsection{Quantity surveying education in Nigerian Universities}

A quantity surveyor is a professional consultant appointed by the client to advise him (the client), architects and engineers on all financial and contractual matters arising from the commencement of a construction project to its completion (Yakubu, 2013). Nigerian Institute of Quantity Surveyors (NIQS) (2015) defined quantity surveying as a profession within the building and engineering construction sector of the economy concerned with cost and procurement management from conception to close-out of any construction project. Ashworth and Hogg (2007) described quantity surveying as the profession concerned with the prudent management of resources of the construction industry. Majorly, a quantity surveyor oversees the allocation of construction resources to the various work items of a project. Thus, a quantity surveyor may be understood as a construction economist and manager responsible for the economic and prudent allocation and utilisation of construction resources in construction projects of all ramifications. The $21^{\text {st }}$ century construction process demands that all the key project participants, including quantity surveyors, should demonstrate visible leadership and commitment to matters concerning workers' health, safety and wellbeing.

The National University Commission (NUC) of Nigeria is responsible for benchmarking minimum academic standards for all undergraduate programmes in Nigeria including that of quantity surveying. A review of the NUC's benchmark minimum academic standard (BMAS) for the quantity surveying 
undergraduate degree programme (NUC, 2007) reveals that construction $\mathrm{H} \& \mathrm{~S}$ is neither among the core courses nor among the elective courses prescribed. However, it should be noted that Nigeria's National Policy on Education enjoins universities to determine the courses to be taught in line with the minimum standards stipulated by regulatory agencies [Nigerian Educational Research and Development Council (NERDC), 2013] like the NUC and the and the Quantity Surveyors Registration Board of Nigeria (QSRBN). The NUC did not stipulate any separate construction H\&S module for the undergraduate quantity surveying programme in the 2007 BMAS, likewise the QSRBN. QSRBN (2017) stated that the Board "monitors teaching, learning and research in quantity surveying in higher institutions of learning to ensure they conform to laid down standards", uncertainty exists as to what standards the QSRBN expects, especially, with respect to construction H\&S. Jagboro (2013) observed that irrespective of the lofty visions of universities with respect to teaching and learning, it appears that no concerted effort is being made to harness and consolidate R\&D efforts in the quantity surveying profession. The impact of this policy gap on Nigerian quantity surveying graduates as it relates to construction H\&S remains a matter of conjecture.

It would appear that Nigeria does not take construction H\&S seriously. For instance, Idoro (2008) pointed out that frequent references are made to international occupational health and safety standards in the Nigerian construction industry. This anomaly which persists till today, coupled with the absence of a dedicated construction H\&S course module in NUC's first degree programme in quantity surveying, betrays a neglect of construction H\&S whose impact at the site level in Nigeria has scarcely been investigated.

Wallerstein and Weinger (1992:619) identified three issues that must be addressed before worker H\&S education can advance, namely: the lack of clarity and consensus on the goals of worker education, the lack of standards for effective teaching methods, the lack of skills in these methods of the people who deliver the trainings. Nigeria's case appears to be dominated by the first issue. As argued by Idoro (2008), apart from the Factories Act of 1987 (CAP F1, Laws of Federation of Nigeria, 2004), which draws heavily from the United Kingdom's Factories Act of 1937 (Hameed, 2013), no other international construction H\&S regulation has the force of law in Nigeria. In any case, the Factories Act has so far been poorly enforced (Abubakar, 2015). Additionally, the Act does not make any reference to tertiary education training of would-be construction professionals. Thus, construction educators may be inadequately incentivised to develop a course content for construction H\&S that is tailored to the needs of Nigeria. The final outcome of this situation will be sets of quantity surveying graduates that are unaware and unprepared for construction $H \& S$ cost management. This could have grave consequences for construction $H \& S$ in Nigeria since construction $H \& S$ training and education is critically important to the H\&S performance of projects (Sawacha, Naoum, \& Fong, 1999). HSE (2008) and Gambatese (2008) observed that construction H\&S education improves the H\&S performance of projects by ensuring positive attitudinal and cultural changes by practitioners in the industry, including quantity surveyors. Jagboro (2016) pointed out that quantity surveyors' roles are becoming more vital for the attainment of sustainable national development goals, including in the area of health, safety and welfare of the workforce, than when it was originally established in England in 1785. The focus of this study, therefore, is to examine the level of awareness of construction H\&S by undergraduate quantity surveyors in Nigeria.

\subsection{Materials and Methods}

In order to achieve the objective of this study, a field survey involving 400 and 500 levels undergraduate quantity surveying students in five federal universities in Southern Nigeria was conducted. These levels of undergraduates are in the penultimate and final years of their studies respectively. Since the data was collected for each university during the second semester, the students must have also completed the mandatory student industrial work experience scheme (SIWES) programme. Thus, they are supposed to understand construction H\&S-related issues. Southern Nigeria was chosen for this study given that it has a higher concentration of higher education institutions than northern Nigeria (Bamiro, 2012).

The universities were selected purposively. Copies of the questionnaire were distributed to 150 students of the stated category. The main purpose of the questionnaire was to determine respondents' level of awareness of the importance of construction H\&S. Of the 150 copies of the questionnaire distributed, only eighty copies $(\mathrm{n}=80,53 \%)$ were returned. The response rate achieved for this research is similar to that achieved in other similar surveys (Sutrisna, 2009; Collins, 2008). It could be inferred from 
Sutrisna (2009) and Dainty (2008) that performing a statistical analysis in a survey within the response rate equal to or above the threshold of thirty (30) is acceptable. Thus, the 53\% response rate achieved in this survey provides reasonable data for analysis. The gathered data were analysed using mean scores (MS). The significance of each variable was ascertained based on the MS average of 2.5. Hence variables having $\mathrm{MS} \geq 2.5$ were considered to be informative, while variables with $\mathrm{MS}<2.5$ were considered unimportant.

In order to confirm the findings of the survey, interviews were also conducted with practicing quantity surveyors and one quantity surveying lecturer from each of the five universities covered by the study. The selection of quantity surveying practitioners and academics for the interviews took account of a number of factors including academic qualifications and years of experience. An interview is an interaction between two or more people to gain insight relative to problems (Leedy \& Ormrod, 2010).

The study further examined the course contents of the quantity surveying programmes of the surveyed universities in order to ascertain whether a separate course module was designated for construction $\mathrm{H} \& \mathrm{~S}$.

\subsection{Results and Discussion}

The analysis of questionnaire survey shows that $37.5 \%$ of the respondents were female while $62.5 \%$ were male. The respondents were between the ages of 18 and 30 years. In view of their years of study in the universities, they were considered academically qualified to comprehend the questions and provide reliable answers.

\subsection{Inclusion of construction $H \& S$ in quantity surveying undergraduate programme}

Despite the contents of the Benchmark Minimum Academic Standards for Undergraduate Programmes in Nigerian Universities (BMAS) for environmental sciences, Nigerian universities are allowed to complement the standard courses with other relevant courses to make for better quality graduates. This necessitated the inquiry into whether construction $H \& S$ is included as a separate course in the curriculum of the B.Sc QS programme of any of the universities of which the students are aware.

The students were asked, "Kindly indicate how construction H\&S is taught in your degree programme in this university"

Table 1 indicates the respondents' responses in terms of 'as a separate course' 'included in other courses' not taught in our programme' and 'Not sure'. The data analysis shows that $62.5 \%$ of the students stated that construction H\&S is taught as an integral part of other courses, while $30 \%$ answered, 'not taught in our programme' $7.5 \%$ of the respondents were not sure whether construction $\mathrm{H} \& \mathrm{~S}$ is included in the degree programmes or not. None of the students indicated that construction H\&S is a separate course in any of the universities. Further, this study's search on the course contents of the quantity surveying programmes of the universities did not reveal any separate course title for construction H\&S.

Thus, both the NUC and the universities studied did not allow for construction H\&S as a separate course in the undergraduate quantity surveying programme. This implies that the training of undergraduate quantity surveyors does not place high emphasis on construction H\&S. Dodo (2014) and Umeokafor, Umeadi, and Igwegbe (2014) revealed that the Federal Ministry of Labour and Productivity which was assigned the responsibility of monitoring compliance to the Factories Act 1987 is not doing so effectively. Consequently, construction companies are not under any pressure to evaluate the construction $\mathrm{H} \& \mathrm{~S}$ competences of their quantity surveying employees. Although the quantity surveying practitioners interviewed expressed the opinion that construction H\&S should be made a separate module, this viewpoint has not gathered sufficient support to compel universities to single out construction H\&S as a separate course of study. Indicatively, one of the goals of education in Nigeria which is to ensure periodic review, effectiveness and relevance of the curriculum at all levels to meet the needs of society and the world of work (NERDC, 2013) has not been achieved in this particular regard. 
Table 1: Construction H\&S into quantity surveying education

\begin{tabular}{lcc}
\hline & Frequency & $\%$ \\
\hline Not taught in our programme & 24 & 30 \\
Included in other courses & 50 & 62.5 \\
Not sure & 6 & 7.5 \\
As Separate course & 0 & 0 \\
Total & $\mathbf{8 0}$ & $\mathbf{1 0 0}$ \\
\hline
\end{tabular}

\subsection{Awareness of quantity surveyors' $H \& S$ roles in construction $H \& S$ management}

Further, the students were asked to indicate quantity surveyors' construction H\&S management roles of which they are aware. The findings are shown in Table 2. The questions were framed in the negative to ensure that the students are sure of the answer before answering. Secondly, the intention was to minimise social desirability bias in the responses (Fisher \& Tellies, 1998). As shown in Table 2, most of the students rated the negative statements related to quantity surveyors' construction H\&S roles high with all the MSs being >3.00. Clearly, the result shows that the students are not aware of QS's roles in construction H\&S. This is related to the non-inclusion of construction H\&S as a separate module in their curriculum.

Mohd-Kamar et al. (2014) found the level of awareness of construction H\&S to be high for class A contractors in Kelantan, Malaysia. This is not supported by the present study. Firstly, it should be noted that Mohd-Kamar et al. (2014) focused on firms, while the present study focused on individuals. Secondly, while Mohd-Kamar et al. (2014) did not reveal the professions of the staff of the firms covered who responded to the questionnaire, this study's questionnaire was administered on quantity surveying undergraduates. Even though class A contractors in Kelantan, Malaysia are highly aware of the importance of construction $\mathrm{H} \& \mathrm{~S}$, undergraduate quantity surveying students in southern Nigerian universities are mostly unaware of the roles of quantity surveyors in construction H\&S. During the interview, the practicing quantity surveyors and lecturers showed support for the idea that undergraduate quantity surveyors should be trained in construction H\&S. However, the practicing quantity surveyors were not all in agreement that construction $H \& S$ knowledge is one of the criteria for the employment of graduate quantity surveyors.

Table 2: Awareness of quantity surveyors' H\&S roles in construction H\&S management

\begin{tabular}{lll}
\hline Statement & MS & Rank \\
\hline Inadequate provision of Sections of Standard Form of Contract Clauses related to H\&S & 3.63 & 1 \\
Failure to ensuring that contractors made adequate financial provision in tenders & 3.61 & 2 \\
Non-inclusion of an H\&S in bills of quantities (BoQs) & 3.56 & 3 \\
Lack of commitment in preparation of periodic valuation certificate & 3.50 & 4 \\
Inadequate facilitation of financial provision for H\&S in the preliminary and general & 3.34 & 5 \\
Lack of pre-qualification of contractors on H\&S & 3.30 & 6 \\
Poor choice of procurement system & 3.15 & 7 \\
Inadequate estimation of project duration & 3.10 & 8 \\
\hline
\end{tabular}

\subsection{Importance of effective construction $H \& S$ management}

Table 3 indicates the extent to which the respondents rated importance of construction $\mathrm{H} \& \mathrm{~S}$ management in terms of mean scores. All the MSs are above the mid-point of 2.50 (MSs $>4.20 \leq 5.00$ ), which indicates that the identified statements are very important.

Overall, the result shows that the students consider effective construction H\&S management to be important. Although they ranked reduction of injuries and disease highest $(\mathrm{MS}=4.58)$, and ranked tarnished contractor' image least $(\mathrm{MS}=4.24)$, all the statements have MS $>4.00$. The findings of this study suggest that even though most of the students do not know the roles of quantity surveyors in the 
construction H\&S management of projects, they are highly aware of the importance of construction $\mathrm{H} \& \mathrm{~S}$.

The findings of Mohd-Kamar, et al. (2014) is supported by this section's results. Student quantity surveyors, just like the firms in Mohd-Karmar, et al.'s (2014) study, are aware of the importance of construction $\mathrm{H} \& \mathrm{~S}$, what is lacking is their understanding of the roles of quantity surveyors in the management of construction H\&S. Muiruri and Mulinge (2014) recommended that massive education campaigns be launched to arouse awareness among all parties with direct or indirect bearing on accidents occurrence and their prevention. The current study's findings suggest that such a campaign should also focus on universities in the southern part of Nigeria, and specifically, at informing undergraduate quantity surveyors on what their future roles will be in terms of construction H\&S management.

Table 3: Importance of effective construction H\&S management

\begin{tabular}{lll}
\hline Factor & MS & Rank \\
\hline Reduction of injuries and disease & 4.58 & 1 \\
Significant reduction in loss of human lives & 4.54 & 2 \\
Reduction of damage to plant and equipment & 4.42 & 3 \\
Reduction in workers absenteeism & 4.41 & 4 \\
Decrease in productivity and profit margin & 4.35 & 5 \\
Reduction in compensation paid to injured workers & 4.33 & 6 \\
Reduction in disputes and litigation & 4.30 & 7 \\
Tarnished contractors' image & 4.24 & 8 \\
\hline
\end{tabular}

\subsection{Interview results}

The interview results show that quantity surveying practitioners are aware of the importance of $H \& S$ and roles quantity surveyors play in construction H\&S management.

However, there were different perceptions among lecturers on the inclusion of construction $H \& S$ as a course module rather than to be offered as integral parts of other courses. A lecturer from one of the universities stated that "construction H\&S is taught alongside other courses such as workshop practice, fire prevention, control and equipment". This corroborates the findings of this study with respect to the inclusion of construction $\mathrm{H} \& \mathrm{~S}$ in the quantity surveying undergraduate programme. In contrast, another lecturer emphatically stated that "there is a need to include construction H\&S as course module in quantity surveying curriculum especially in Nigeria". He stated that "quantity surveyors as construction cost experts who advise clients and architects on the implications of their design decisions should have knowledge of the national and international H\&S legislations and regulations". While every other interviewee agreed with this perspective, this study's finding is that construction H\&S is not a separate module in the course content of the quantity surveying programmes of the universities surveyed.

All the practicing quantity surveyors interviewed indicated that there is need to include construction $\mathrm{H} \& \mathrm{~S}$ as a course module in quantity surveying programmes in tertiary institutions in Nigeria. One of the interviewees stated "I will carry this message to the next Nigerian Institute of Quantity Surveyors (NIQS) Lagos State Branch meeting". He stated further that, "It is high time the Nigerian quantity surveyors contributed to construction industry H\&S improvement, not limiting their roles only to the preparation of bills of quantities". All the interviewees agreed that quantity surveyors, as financial experts in the construction industry can contribute significantly to the industry's H\&S performance. Literature review corroborated the views of the practicing quantity surveyors that quantity surveying students need an appreciation and understanding of construction $\mathrm{H} \& \mathrm{~S}$ for their future $\mathrm{H} \& \mathrm{~S}$ critical roles and to develop a safety-first mindset (HSE, 2008).

\subsection{Conclusion and Recommendations}

The education of future quantity surveyors is fundamental to the desired cultural change for construction industry H\&S improvement. This is the rationale behind this study that sought to examine the 
construction H\&S awareness of undergraduate quantity surveying students in universities in southern Nigeria.

This study has revealed that the knowledge of construction H\&S management is important to students of quantity surveying. From the research findings and interviews, it is apparent that $\mathrm{H} \& \mathrm{~S}$ is not included as a course module, but taught as an integral part of other courses. Construction H\&S is, therefore, not designated as an area of separate study for quantity surveying undergraduates in the universities covered by this study. It was, however, determined that the students are aware of the importance of construction $\mathrm{H} \& \mathrm{~S}$ in the construction industry, although they were found not to know exactly the construction $\mathrm{H} \& \mathrm{~S}$ roles of quantity surveyors. This knowledge gap has implications for the effective management of construction H\&S in Nigeria.

Based on the findings of this study, the NUC should include construction H\&S as a separate course module for quantity surveying undergraduate programmes with a view to abating the rate of $\mathrm{H} \& \mathrm{~S}$ failures in the Nigerian construction industry. Universities in the study area should include construction $\mathrm{H} \& \mathrm{~S}$ as one of the courses to be taught at the undergraduate level for quantity surveying students, even if the NUC does not do so. In addition, excursions and similar means should be adopted in the construction H\&S training of undergraduate quantity surveying students. The NIQS should develop quantity surveying based best practice manual/note in the area of construction H\&S management for circulation to undergraduate students.

\section{References}

Abubakar, U. (2015). An Overview of the Occupational Safety and Health Systems of Nigeria, UK, USA, Australia and China: Nigeria Being the Reference Case Study. American Journal of Educational Research, 3(11), 1350-1358.

Arewa, A.O. \& Farrell, P. (2012). A review of compliance with health and safety regulations and economic performance in small and medium construction enterprises. In: Smith, S.D (Ed) Procs 28th Annual ARCOM Conference, 3-5 September 2012, Edinburgh, UK, Association of Researchers in Construction Management, 423-432.

Ashworth, A. \& Hogg, K. (2007) Willis's practice and procedure for the quantity surveyor, $12^{\text {th }}$ ed. Oxford, Blackwell Science, pp. 23-25.

Ayudhya, N., \& Israngkura, B. (2011). Common disputes related to public work projects in Thailand. Songklanakarin Journal of Science \& Technology, 33(5).

Bamiro, O. A. (2012). Tertiary Education in Nigeria and the Challenge of Corporate Governance. Speech at the TETFund Year 2012 Strategic Planning Workshop, held at the Idris Abdukadir Auditorium, National Universities Commission, Maitama Abuja, 7th to 8th August, 2012

Collins, H. (2008) Creative research: the theory and practice of research for the creative industries. Lausanne: AVA Publishing SA, pp.57-67.

Coke, A. \& Sridhar, C. (2010) Controlling exposure to biological hazards, In: McAleenan, C. \& Oloke, D. ed. ICE manual of health and safety in construction. London: Thomas Telford, 135-148.

Dainty, A.R.J. (2008). Methodological pluralism in construction management research: In A. Knight and L. Roddock, eds. Advanced Research Methods in the Built Environment, Oxford: Willey-Blackwell, pp.1-13.

Dodo, M. (2014). The application of health and safety plan in Nigerian construction firms. Journal of Civil Engineering, 8(1) 81-87

European Agency for Safety and Health at Work Act (2011) "Achieving better safety and health in construction" London: HMSO, pp.28-30. 
Famakin, I. O. \& Fawehinmi, O. S. (2012). Quantity surveyors' perception of construction health and safety regulation in Nigeria. Journal of Building Performance, 3(1): 1-9

Fisher, R. J. \& Tellis, G. J. (1998). Removing social desirability bias with indirect questioning: Is the cure worse than the disease? Advances in Consumer Research, 25, 563-567

Gambatese, J.A. (2008) Research issues in Prevention through Design: Journal of Safety Research; 39(2), 153-156.

Hameed, T. (2013). The Factories Act and the development of occupational health and safety in Nigeria Labour Law Review NJLIR 7(3), 24-63

Haupt, C. (2010). Controlling Exposure to Physical Hazards, In McAleenan, P. and Oloke, D. ed. ICE Manual of Health and Safety, London: Thomas Telford, pp. 149-162.

Health and Safety and Executive (HSE, 2010) Reducing error and influencing behaviour: HSE48.HSE, Book.

Health and Safety Executive (2008) Workers-Related Deaths: Protocol for Liaison, London: HMSO.

Health and Safety and Executive (HSE, 2011) Why did it happen? HMSO: pp. 211-214.

Hinze, J.W. (2006) Construction Safety, Prentice- Hall Inc. Upper Saddle New Jersey: USA, pp.67-81, 2006.

Hughes, P. \& Ferrett, E. D. (2010) Introduction to Health and Safety in Construction, London: Butterworth-Heinemann

International Labour Organisation (2011). Malawi National Occupational Safety and Health Programme 2011-2016 Moving Towards Zero Accidents and Diseases at Work . Retrieved from http://www.ilo.org/wcmsp5/groups/public/---ed_protect/---protrav/--safework/documents/policy/wcms_221740.pdf

International Labour Organisation (ILO, 2010) Standards on occupational safety and health: promoting a safe and healthy working environment, Geneva: ILO: pp.12-13.

Idoro, G. I. (2008). Health and safety management efforts as correlates of performance in the Nigerian construction industry, Journal of Civil Engineering and Management, 14:4, 277-285

Jagboro, G. O. (2013). Keynote paper 2: research and development in QS profession - Nigeria scorecard. In: A. D. Ibrahim, K. J. Adogbo \& Y. M. Ibrahim (Eds). Proceedings of Nigerian Institute of Quantity Surveyors: $1^{\text {st }}$ Annual Research Conference - AnRecon. $3^{\text {rd }}-5^{\text {th }}$ September, 2013. Ahmadu Bello University Press Limited, Zaria. 21-27

Jagboro, G.O. (2016) Unmasking the tower of babel and the scourge of abandoned projects in Nigeria; Obafemi Awolowo University: Ile-Ife, Inaugural lecture series, 286, pp.2-3.

Kheni, N.A. (2008) Impact of health and safety performance of small and medium sized construction businesses in Ghana, Unpublished doctoral thesis, Loughborough University: UK, pp123-124.

Leedy, D. \& Ormrod, J. (2010) Practical research planning and design, $5^{\text {th }}$ Edition, New Jersey: Pearson, pp.231-232.

Luria, G. (2011) The social aspects of safety management: trust and safety climate. Accident Analysis and Prevention, 42(1), 1288-1295.

Lutchman, C., Maharaj, R. \& Ghanem, W. (2012) Safety management: A comprehensive approach to developing a sustainable system: 1 st (Ed.), New Jersey: CRC Press. 
Mohamed, S. (2002). Safety climate in construction site environments. Journal of construction engineering and management, 128(5), 375-384.

Mohd-Kamar, I.F., Lop, N.S., Mat-Salleh, N., Mamter, S. and Suhaimi, H.A. (2014) Contractor's Awareness on Occupational Safety and Health (OSH) Management Systems in Construction Industry. Retrieved from http://www.e3s-conferences.org

Muiruri, G., \& Mulinge, C. (2014). Health and Safety Management on Construction Projects Sites in Kenya: A Case Study of Construction Projects in Nairobi County. In FIG Congress 2014 held in Kuala Lumpur, Malaysia 16-21 June.

National University Commission (NUC) Regulatory Policy on Minimum Academic Standards for Undergraduate Programmes in Nigeria Universities, Environmental Sciences (2017).

Nigerian Educational Research and Development Council (NERDC) (2013). National Policy on Education ( $6^{\text {th }}$ Edition). Lagos: NERDC

Nigerian Institute of Quantity Surveyors (NIQS) (2015). Welcome to the Nigerian Institute of Quantity Surveyors. Retrieved http://niqs.org.ng/

Nishgaki, S. (1994). Humanware, human error and Hiyari-hat: a template of unsafe symptoms, Journal of Construction Enginering and Management, 120 (2), pp.421- 41.

Ofoegbu, F.I. (2004) Supervision and inspection in the Nigeria Education system, In N.A. Nwaegwu, M.E. Ijoma \& C.C.Nwagwu (eds.) Organisational and Administrative of Education Perspectives and Practice, Benin City, FESTA, 232.

Okorie, V.N. (2014) Behaviour-based health and safety management in construction: A leadershipfocused approach. Unpublished PhD Thesis: Nelson Mandela Metropolitan University, Port Elizabeth, Department of construction management, pp.153-154.

Okoye, P. U., Ezeokonkwo, J. U. \& Ezeokoli, F. O. (2016). Building Construction Workers' Health and Safety Knowledge and Compliance on Site, Journal of Safety Engineering, 5(1), pp. 17-26. doi: 10.5923/j.safety.20160501.03.

Oloke, A.O. (2010) Responsibility of Key Duty Holders in Construction Design and Management. In McAleenan, C. \& Oloke, D. ed. ICE Manual of Health and Safety in Construction, London: Thomas Telford, 29-37.

Quantity Surveyors Registration Board of Nigeria (QSRBN) (2017). QSRBN Services: training and education. Retrieved from http://www.qsrbn.gov.ng/Services/education.php

Sawacha, E., Naoum, S., \& Fong, D. (1999). Factors affecting safety performance on construction sites. International journal of project management, 17(5), 309-315.

Spangenberg, S. (2009) An Injury Risk Model for Large Construction Projects, Risk Management an International Journal, 11 (2), 111-129.

Smallwod, J. J. 2004. The Influence of Architectural Designers on Health and Safety during Construction, In: T.C. Haupt (ed) $3^{\text {rd }}$ South African Construction Health and Safety Conference. Team approach to Construction Health and Safety, Cape Town, 7-8 May, Walmer, Port Elizabeth: CREATE 29-46.

Sodipo, O. O. (2014). Employability of Tertiary Education Graduates in Nigeria: Closing the SkillsGap, Global Journal of Human Resource Management, 2(3): 28-36

Sutrisna, M. (2009) Research methodology in doctorial research: understanding the meaning of conducting qualitative research: Working Paper Presented in ARCOM Doctorial Workshop, Liverpool, John Moores University, May, 12, pp.34-35. 
Udo, U. E., Usip, E. E. \& Asuquo, C. F. (2016). Effect of Lack of Adequate Attention to Safety Measures on Construction Sites in Akwa Ibom State, Nigeria, Journal of Earth Sciences and Geotechnical Engineering, 6(1): 113-121

Umeokafor, N, Umeadi, B., Jones, K \& Igwegbe, O. (2014). Compliance with occupational safety and health regulations in Nigeria's public regulatory entity: a call for attention. International Journal of Scientific and Research Publications, 4(5): 1-3

Wallerstein, N., \& Weinger, M. (1992). Introduction: Health and safety education for worker empowerment. American Journal of Industrial Medicine, 22(5), 619-635.

Yakubu, I. (2013) Quantity surveying education- status report on Nigeria, Nigerian Institute of Quantity Surveyors: First Annual Research Conference - ANRECON 3rd to $5^{\text {th }}$ September 2013. 